Why is Tax Knowledge and Tax Understanding Important?

by Jeni Susyanti, Noor Shodiq Askandar

\title{
Why is Tax Knowledge and Tax Understanding Important?
}

\author{
Jeni Susyanti *) \\ Noor Shodiq Askandar **)
}

\begin{abstract}
Micro, small, and medium (MSMEs) business play a crucial role in the economy of Indonesia. Unfortunately, there is low-income tax receipt from MSME sectors. This study examined the effect of taxation knowledge and understanding toward tax compliance among MSMEs owners, exclusively culinary business owners. The quantitative method was used in analyzing the data collected. The sample size for the research was 50, with all MSME owners responded through the questionnaire distributed. This study concluded that there is a positive effect between taxation knowledge and level of understanding toward tax compliance. It means that an increase in tax knowledge and tax understanding level can lead to an increase of tax compliance level. Although this study succeeded to prove the effect between variables, the results of secondary data indicate that many MSME owners are still confused in implementing tax regulations, PP$23 / 2018$.
\end{abstract}

Keywords: Tax Compliance; Tax Knowledge; Level of Understanding; MSME

\section{INTRODUCTION}

\subsection{Research Background}

Taxation is the primary source of income for a state. The tax collection target that amounted IDR 1.42 Quadrillion in 2018 made the government make various tax regulations that will affect positively and negatively to multiple economy sectors, including MSMEs sector. MSMEs itself play a crucial role in the economy of Indonesia. They are expected to be a backbone of the government income through regional taxes and levies. MSMEs that run either by individuals or entities have an obligation to pay taxes in Indonesia. In addition to their duties as self-assessment, taxpayers are also obliged to cut and collect taxes (Susyanti \& Dahlan, 2016). Unfortunately, the increasing number of MSMEs entrepreneurs did not affect the tax contribution (Susyanti, 2014). There are several factors that influences tax compliance including referral groups, the probability of audit, tax knowledge, and the perception of equity and fairness (Inasius, 2018), tax education (Kwok \& Yip, 2018; Aladejebi, 2018), political factors, such as lack of transparency due to weak news media, sociological, cultural factors, such as weak national identity (Bessley \& Persson, 2014), level of understanding (Adiasa, 2013; Agustiningsih \& Isroah, 2016), lack of adequate knowledges (Fallan, 1999; Omagor \& Mubiru, 2008; Manual \& Xin, 2016; Newman, Charity, \& Ongayi, 2018). Susyanti (2014) argues that the lack of tax knowledge and understanding of MSMEs owners is the main detention in fulfilling tax obligations. Therefore, it is necessary. Therefore, there is a need to continually grow public awareness and compliance of taxpayers to fulfill tax obligations in accordance with applicable regulations.

\subsection{Research Problem}

a) How is the effect of taxation knowledge and taxation understanding on tax compliance simultaneously?

b) How is the effect of taxation knowledge and taxation understanding on tax compliance partially?

JEMA: Jurnal Ilmiah Bidang Akuntansi dan Manajemen is licensed under a Creative Commons Attribution 4.0 International License 


\subsection{Research Purpose}

The purpose of the study was to understand and analyze the effect of taxation knowledge and taxation understanding on tax compliance both simultaneously and partially.

\section{THEORETICAL FRAMEWORK AND HYPOTHESES DEVELOPMENT}

\subsection{The Effect Between Tax Knowledge and Tax Compliance}

Tax knowledge, in a simple term, can be defined as the taxpayer ability to understand the tax laws and regulations (Ayuba, Saad, \& Arifin, 2016). Pratama (2018) added that tax knowledge is a level of knowledge of basic tax concept that consists of tax rules and financial knowledge that needs to be understood by taxpayers in order to fulfill their tax obligations (Pratama, 2018). Gore \& Wong (1998) divided tax knowledge into categories, procedural knowledge (knowing how) and declarative knowledge (knowing that). Previous research from Fallan (1999), Omagor \& Mubiru, (2008), Manual \& Xin (2016), Newman, Charity, \& Ongayi (2018) concluded that there is a relationship between tax knowledge and tax compliance, an increase of tax knowledge level can lead to the increase of tax compliance level.

\subsection{The Effect Between Tax Understanding and Tax Compliance}

Sulistiani, \& Jayanto (2016) defined tax understanding as to the understanding or knowledge possessed by the taxpayer related to taxation. Satria (2017) added that tax understanding is the perception of taxpayer toward their knowledge about taxation. Tax understanding is the level of knowledge and ability of taxpayers concerning the enactment and the implementing regulations of the tax law both in content and administration. Previous research from Adiasa (2013), Agustiningsih \& Isroah (2016) concluded there is a relationship between tax understanding and tax compliances. Thus, the higher tax understanding can lead to higher compliance.

Therefore, the hypothesis proposed in this study is;

$\mathrm{H}_{1}$ : Tax knowledge and tax understanding have a partial significant effect toward tax compliance.

$\mathrm{H}_{2}$ : Tax knowledge and tax understanding have a simultaneous significant effect toward tax compliance.

\section{RESEARCH METHOD}

\subsection{Research Design}

This study can be classified as quantitative descriptive research. The primary data collection technique was done by giving questionnaires to respondents. While the secondary data collection technique was done through recording, documents related to the business profile and the types of activities. Based on the questionnaire feedback, it can be determined (measured) the frequency distribution for each variable, so that it can be known whether the intention to comply tax is good (indicated by high score) or poor (indicated by low scores). Tarigan (2012) determined the formula as follows;

Range $=\frac{(\text { highest score }- \text { lowest score })}{\text { number of answer categories }}=\frac{(5-1)}{5}=0,8$


Table 1 Respondent Perception Levels

\begin{tabular}{|c|c|}
\hline Mean Range of Respondent's Answer Scores & Respondent's Perception Level \\
\hline $1,00-1,80$ & Very bad \\
\hline $1,81-2,60$ & Bad \\
\hline $2,61-3,40$ & Good Enough \\
\hline $3,41-4,20$ & Good \\
\hline $4,21-5,00$ & Very good \\
\hline
\end{tabular}

Source: Tarigan (2012)

\subsection{Population and Sample}

The population in this study is the MSME owners in Malang, East Java, Indonesia, exclusively culinary industry. The reason in choosing culinary industry and Malang as a research subject is because those subjects are recorded strong growth and contribute quite significantly to the total income of the tourism sector and the creative economy last year. All population or 50 culinary owners in Malang participate in this study.

\subsection{Research Framework}

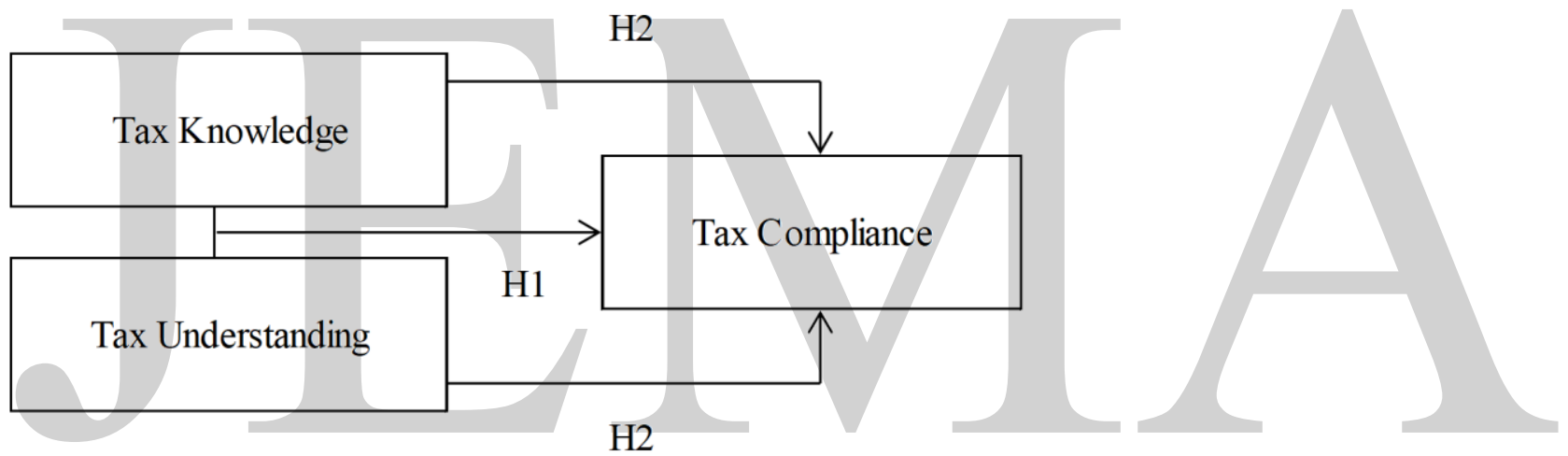

Picture 1 Research Framework

\section{RESEARCH RESULT AND ANALYSIS}

\subsection{Descriptive Analysis}

The culinary owners who have a thematic culinary service business were $54 \%$ while culinary owners that have their owned unique product was $46 \%$. Female is the majority of the respondent in this study (52\%) with most of the culinary business were driven by young people.

According to Rachmawati (2017), the business is categorized as a micro business if it has a maximum total revenue of IDR 500 million. While the small business has total revenue between IDR 500 million - 2.5 billion, the medium business has total revenue beyond IDR 2.5 billion. Table 2 described that the majority of the respondent in this study got maximum IDR 1.000.000.000 for total revenue, it means that this sector has the potential to become a powerful force to encourage total income of the tourism sector and the creative economy shortly. 
JEMA: Jurnal Ilmiah Bidang Akuntansi dan Manajemen, Vol. 16 No. 2 (2019)

http://riset.unisma.ac.id/index.php/jema (e-ISSN : 2597-4071)

Table 2 Culinary Business Total Revenue

\begin{tabular}{|c|l|c|c|}
\hline No & \multicolumn{1}{|c|}{ Total Revenue } & Total Owner & Percentage \\
\hline 1 & $\leq$ IDR 500.000.000 & 16 & $32 \%$ \\
\hline 2 & IDR 500.000.001-1.000.000.000 & 10 & $20 \%$ \\
\hline 3 & IDR 1.000.000.001-1.500.000.000 & 7 & $14 \%$ \\
\hline 4 & IDR 1.500.000.001-2.000.000.000 & 8 & $16 \%$ \\
\hline 5 & IDR 2.000.000.001-2.500.000.000 & 5 & $10 \%$ \\
\hline 6 & IDR 2.500.000.000 and above & 4 & $8 \%$ \\
\hline & Total & 50 & $100 \%$ \\
\hline
\end{tabular}

Source: Primary Data Processed, 2018

Based on Table 3, it was found that the respondent has a good enough perception $(3,24)$ to the procedures in paying taxes. Uniquely, the respondent has a poor perception $(2,16)$ about the function and benefits of Tax Identification Number (NPWP).

Table 3 Mean Score of Taxation Knowledge

\begin{tabular}{|c|l|c|l|}
\hline No & \multicolumn{1}{|c|}{ Questionaire } & Mean & Decision \\
\hline 1 & $\begin{array}{l}\text { I know the general understanding of taxes, } \\
\text { NPWP, WPOP, Corporate WP, } \\
\text { Entrepreneurs, and SPT. }\end{array}$ & 3,00 & Good Enough \\
\hline 2 & $\begin{array}{l}\text { I know how the procedure for paying } \\
\text { taxes. }\end{array}$ & 3,24 & Good Enough \\
\hline 3 & $\begin{array}{l}\text { I know the function and benefits of the } \\
\text { Tax Identification Number. }\end{array}$ & 2,16 & Bad \\
\hline 4 & $\begin{array}{l}\text { I know the tax collection, the basis of tax } \\
\text { collection and may or not the taxpayer pay } \\
\text { it in installments. }\end{array}$ & 3,18 & Good Enough \\
\hline 5 & $\begin{array}{l}\text { I know the basic of accountancy and } \\
\text { recording, which must be done by } \\
\text { taxpayers in general. }\end{array}$ & 3,12 & Good Enough \\
\hline
\end{tabular}

Source: Primary Data Processed, 2018

Meanwhile, Table 4 shows that the respondent had good enough perceptions of all questionnaire item in tax understanding. They know what is the general provisions of taxation, tax deposits, and tax reporting about. They also know how to fill and calculating tax.

Table 4 Mean Score of Tax Understanding

\begin{tabular}{|c|l|c|l|}
\hline No & \multicolumn{1}{|c|}{ Questionaire } & Mean & \multicolumn{1}{|c|}{ Decision } \\
\hline 1 & $\begin{array}{l}\text { I understand the general provisions of } \\
\text { taxation. }\end{array}$ & 3,10 & Good Enough \\
\hline 2 & I understand how to fill SPT. & 3,22 & Good Enough \\
\hline 3 & I understand the calculation of tax. & 3,24 & Good Enough \\
\hline 4 & I understand tax deposits. & 3,28 & Good Enough \\
\hline 5 & I understand tax reporting. & 3,24 & Good Enough \\
\hline
\end{tabular}

Source: Primary Data Processed, 2018 
A result from Table 5 indicates that they do not agree with the questionnaire item that states that they registered tax identification number voluntary, and they recorded financial business regularly and consistently.

Table 5 Mean Score of Tax Compliance

\begin{tabular}{|c|l|c|l|}
\hline No & \multicolumn{1}{|c|}{ Questionaire } & Mean & \multicolumn{1}{|c|}{ Decision } \\
\hline 1 & I registered the NPWP voluntarily. & 2,32 & Bad \\
\hline 2 & $\begin{array}{l}\text { I record the financial business regularly } \\
\text { and correctly. }\end{array}$ & 3,32 & Bad \\
\hline 3 & $\begin{array}{l}\text { I fill out, count, and report tax notification } \\
\text { letters honestly, completely, and correctly } \\
\text { in accordance with applicable rules. }\end{array}$ & 3,18 & Good Enough \\
\hline 4 & $\begin{array}{l}\text { I pay taxes voluntarily according to the } \\
\text { rules and on time. }\end{array}$ & 2,96 & Bad \\
\hline 5 & $\begin{array}{l}\text { I consciously carry out enforcement of } \\
\text { taxation sanctions. }\end{array}$ & & \\
\hline
\end{tabular}

Source: Primary Data Processed, 2018

\subsection{Validity and Reliability}

The validity test of the questionnaire was conducted in order to determine the validity of the questionnaire. All constructs of the question in this study can be categorized as a valid and reliable because of they significant in 0,05 (r-value > r-table) and greater than 0,60 for Cronbach Alpha rule.

\subsection{Research Analysis}

The best-fit regression model should fulfill the following classic assumptions, including:

a. Multicollinearity

Based on Table 6, it can be seen that all variables have Tolerance $>0,10$ and VIF value $<10$, thus it can be concluded that the regression model does not have a multicollinearity problem.

Table 6 Multicollinearity Test Results

\begin{tabular}{|l|c|c|}
\hline \multirow{2}{*}{ Variable } & \multicolumn{2}{c|}{ Collinearity Statistics } \\
\cline { 2 - 3 } & Tolerance & VIF \\
\hline Tax Knowledge & 0,949 & 1,053 \\
\hline Tax Understanding & 0,956 & 1,046 \\
\hline
\end{tabular}

Source: Primary Data Processed, 2018

\section{b. Autocorrelation}

The result of the Durbin Watson test is 1,905 , which is greater than -2 and smaller than +2 , it means there is no autocorrelation in the regression model.

c. Heteroscedasticity

The result of the Park test shows that there is no significant result between tax knowledge, tax understanding, and its unstandardized residual $\left(\mathrm{LnUi}^{2}\right)$. Therefore, it concluded that there are no symptoms of heteroscedastiscity from this regression model. 


\section{d. Normality}

Based on the results of the Kolmogorov Smirnov Test (KST), the significance value of the variable is 0,524 , which is greater than $>0,05$. It means that the regression model is normally distributed.

Tabel 2 Regression Result

\begin{tabular}{|c|c|c|c|c|}
\hline Variable & $\begin{array}{l}\text { Regression } \\
\text { Coefficient }\end{array}$ & $\mathrm{t}_{\text {test }}$ & Sig. & Decision \\
\hline Tax Knowledge $\left(\mathrm{X}_{1}\right)$ & 0,959 & 2,158 & 0,000 & Significant \\
\hline Tax Understanding $\left(\mathrm{X}_{2}\right)$ & 0,054 & 0,49 & 0,027 & Significant \\
\hline Constant & \multicolumn{4}{|c|}{1,597} \\
\hline $\mathrm{R}$ & \multicolumn{4}{|c|}{0,954} \\
\hline $\mathrm{R}$ square & \multicolumn{4}{|c|}{0,910} \\
\hline Adjusted R square & \multicolumn{4}{|c|}{0,907} \\
\hline $\mathrm{F}_{\text {test }}$ & \multicolumn{4}{|c|}{23,89} \\
\hline Sig. F & \multicolumn{4}{|c|}{0,00} \\
\hline $\mathrm{N}$ & \multicolumn{4}{|c|}{50} \\
\hline F table & \multicolumn{4}{|c|}{3,20} \\
\hline t table & \multicolumn{4}{|c|}{1,67} \\
\hline Dependent Variable & \multicolumn{4}{|c|}{ Tax Compliance (Y) } \\
\hline
\end{tabular}

Source: Primary Data Processed, 2018

Based on the regression results, the tax knowledge and tax understanding have a partially significant effect on tax compliance because of their significant value that below $0,05(0,000$ and 0,027). This study also concludes that tax knowledge and tax understanding has a significant simultaneous effect on tax compliance because they're a significance value below $0,05(0,00)$. The results of this analysis were strengthened by obtaining the value of the adjusted $\mathrm{R}$ square $\left(\mathrm{R}^{2}\right)$ of 0,907 or $90,7 \%$. It means that tax knowledge and tax understanding can explain $90,7 \%$ of tax compliance. While the remaining $9,3 \%$ was influenced by other variables that are not included in this model.

\subsection{Research Discussion}

The problem of tax compliance is as old as taxes themselves, especially in developing countries like Indonesia (Besley \& Persson, 2014). The result of this study supports previous research conclusion which states that there is the relationship between tax knowledge, tax understanding, and tax compliance both partially and simultaneously (Fallan, 1999; Omagor \& Mubiru, 2008; Newman, Charity, \& Ongayi, 2018; Kwok \& Yip, 2018; Aladejebi, 2018). There is no difference perception between male and female in perceived the importance of tax knowledge and understanding. Surprisingly, although the majority of the respondent in this study has a relatively positive perception about the importance of tax knowledge and understanding item questionnaire, they have low responses in perceiving tax compliance. Susyanti (2014) argues that many MSMEs owners are still confused in implementing tax regulations; PP-23/2018, they only know the tax knowledge and tax understanding in general or average way. Therefore, it is suggested that tax education should begin in the early stages of level eduction such as school (Palil, Akir, \& 
Ahmad, 2013). Hopefully, if the employees had adequate tax knowledge, there would minimalize the unintentional non-compliances.

\section{RESEARCH CONCLUSION AND LIMITATION \\ 5.1 Conclusion}

The result of this study is not difference with another previous study. This study concluded that there is an effect of tax knowledge and tax understanding toward tax compliance, both partially and simultaneously. It means that to enhance the level of tax compliance, stakeholder should increase the knowledge and the level of understanding of the taxpayer. Interestingly, although this study succeeded to prove the effect between variables, the results of secondary data indicate that many MSME owners are still confused in implementing tax regulations, PP-23/2018.

\subsection{Limitation}

The limitation of this study is that the data collection used is only questionnaires based. It means that this research only covered the perceptions of respondents and did not describe the actual situation of respondents. This study also used a limited sample, so the results cannot be generalized. Future research should be done in another type of business and variables.

\section{REFERENCES}

Adiasa, N. (2013). Pengaruh pemahaman peraturan pajak terhadap kepatuhan wajib pajak dengan moderating preferensi risiko. Accounting Analysis Journal, 2(3). https://doi.org/10.15294/aaj.v2i3.2848.

Agustiningsih, W., \& Isroah, I. (2016). Pengaruh Penerapan E-Filing, Tingkat Pemahaman Perpajakan Dan Kesadaran Wajib Pajak Terhadap Kepatuhan Wajib Pajak Di KPP Pratama Yogyakarta. Nominal, Barometer Riset Akuntansi dan Manajemen, 5(2). http://dx.doi.org/10.21831/nominal.v5i2.11729.

Aladejebi, O. (2018). Measuring Tax Compliance among Small and Medium Enterprises in Nigeria. International Journal of Accounting and Taxation, 6(2), 29-40. https://doi.org/10.15640/ijat.v6n2a4.

Ayuba, A., Saad, N., \& Arifin, Z. Z. (2016). Perceived service orientation, economic factors, psychological factors and tax compliance: Evidence from Nigerian SMEs. Malaysian Management Journal, 20, 41-57.

Besley, T., \& Persson, T. (2014). Why do developing countries tax so little?. Journal of Economic Perspectives, 28(4), 99-120. https://doi.org/10.1257/jep.28.4.99.

Fallan, L. (1999). Gender, exposure to tax knowledge, and attitudes towards taxation; an experimental approach. Journal of Business Ethics, 18(2), 173-184. https://doi.org/10.1023/A:1005711905297.

Gore, R., \& Wong, O. W. B. (1998). The acquisition and transfer of tax skills. The Journal of American Taxation Association, 20(2), 117-126.

Inasius, F. (2019). Factors influencing SME tax compliance: Evidence from Indonesia. International Journal of Public Administration, 42(5), 367-379. https://doi.org/10.1080/01900692.2018.1464578. 
Kwok, B. Y. S., \& Yip, R. W. Y. (2018). Is Tax Education Good or Evil for Boosting Tax Compliance? Evidence from Hong Kong. Asian Economic Journal, 32(4), 359-386. https://doi.org/10.1111/asej.12163.

Manual, V., \& Xin, A. Z. (2016). Impact of Tax Knowledge, Tax Compliance Cost, Tax Deterrent Tax Measures towards Tax Compliance Behavior: A survey on Self-Employed Taxpayers in West Malaysia. Electronic Journal of Business and Management, 1(1), 56-70.

Newman, W., Charity, M., \& Ongayi, W. (2018). Literature Review on the Impact of Tax Knowledge on Tax Compliance among Small Medium Enterprises in a Developing Country. International Journal of Entrepreneurship. Retrieved from https://www.abacademies.org/articles/literature-review-on-the-impact-of-tax-knowledge-ontax-compliance-among-small-medium-enterprises-in-a-developing-country-7571.html.

Omagor, C., \& Mubiru, M. (2008). Entrepreneurship: An integrated approach. Kampala: Basic Business Books.

Palil, M. R., Akir, M. R., \& Ahmad, W. F. (2013). The perception of tax payers on tax knowledge and tax education with level of tax compliance: a study the influences of religiosity. ASEAN Journal of Economics, Management and Accounting, 1(1), 118-129.

Pratama, A. (2018). Individual Taxpayer Characteristics and Taxpayer Knowledge: Exploratory Survey on Individual Taxpayers in Bandung City, Indonesia. Review of Integrative Business and Economics Research, 7, 338-349.

Rachmawati, I. K. (2017). Model and Characteristics of Micro Finance Institutions Based on SME Women in Batu City. JEMA: Jurnal Ilmiah Bidang Akuntansi dan Manajemen, 14(01), 21-34. http://dx.doi.org/10.31106/jema.v14i01.214.

Satria, H. (2017). PENGARUH PEMAHAMAN PAJAK, KETENTUAN PERPAJAKAN DAN TRANSPARANSI DALAM PAJAK TERHADAP KEPATUHAN WAJIB PAJAK BADAN PERUSAHAAN JASA KONSULTAN KONSTRUKSI DI KOTA TANJUNGPINANG. AnNisbah: Jurnal Ekonomi Syariah, 4(1), 129-146.

Sulistiani, I., \& Jayanto, P. Y. (2016). Factors Affecting Individual Tax Payers Attitude to Do Tax Evasion (Empirical Study on Apparatus/Public Official in Purbalingga District). Accounting Analysis Journal, 5(4), 352-359.

Susyanti J. (2014). Problems Identification Of Creative Economy Business Actors Of Tourism Sector In Malang City in Effort to Meet Tax Obligations. International Journal of Business and management Invention (IJBMI), 3(11), 13-19.

Susyanti, J., \& Dahlan, A. (2016). Perpajakan untuk Akademisi dan Praktisi. Malang: Penerbit: Empat Dua Media.

*) Jeni Susyanti, Department of Management, University of Islam Malang, Malang, Indonesia (Email: jenysusyanti@ unisma.ac.id)

**) Noor Shodiq Askandar, Department of Accounting, University of Islam Malang, Malang, Indonesia (Email: noorshodiqaskandar@unisma.ac.id) 